\title{
INFLUÊNCIA DO TRAUMA OCLUSAL NA DOENÇA PERIODONTAL
}

Leandro Nicolao BUZZATA; Aguinaldo Coelho de FARIAS; Paulo Afonso CUNALI; Lilian CUSTÓDIO

As interferências oclusais e sua relação com as doenças periodontais sempre foi um tema bastante controverso na literatura. Neste estudo objetivamos através de uma revisão de literatura, avaliar a influência do trauma oclusal na progressão e estabilização de uma doença periodontal. Os estudos de Ribeiro, L. et al e Gher, M. E. afirmam que a mobilidade dentária nem sempre é indicativa de trauma oclusal e que pode existir com ausência de interferência oclusal. Gher ainda relata, nesse estudo, que a mobilidade dentária poderá ser eliminada após o tratamento da doença periodontal, seguida de um ajuste oclusal. Com base nos estudos regressos, podemos concluir que a interferência oclusal faz parte de um conjunto de fatores que pode perpetuar e, principalmente, agravar a doença periodontal promovendo uma maior mobilidade dentária. 